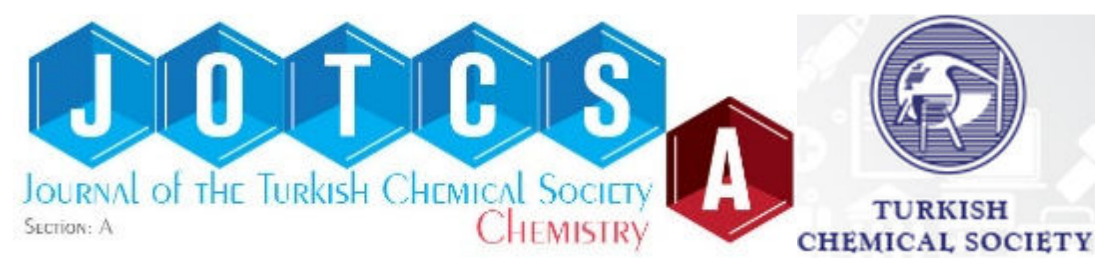

(This article was presented to the 28th National Chemistry Congress and submitted to JOTCSA as a full manuscript)

\title{
Characterization of Magnetic Polymeric Microparticles
}

\begin{abstract}
Kazım Köse
Hitit University, Scientific Technical Research and Application Center, Çorum, Turkey.

Abstract: The separation process is very important in a variety of scientific fields, especially in biochemistry and biotechnology. The separation performance of a method can be determined by the separation time and the purity of the separated molecule, which is directly proportional with the ligand chosen for the target molecule. The separation time is actually a very important step for the cost and the time-dependent analysis, especially in medical applications. Magnetic separation is a very advantageous technique because it eliminates the time-consuming sample preparation and centrifugation steps. However, the magnetic performance of adsorbent may not be strong enough to respond the magnetic force applied externally. Therefore, in nanoparticle studies, magnetic performance of nanoparticles is highly important. In this study, the magnetic performance of polymeric microparticles synthesized using different magnetic cores $\left(\mathrm{Fe}_{2} \mathrm{O}_{3} \& \mathrm{Fe}_{3} \mathrm{O}_{4}, \mathrm{Fe} \& \mathrm{Ni}, \mathrm{Ni} \& \mathrm{Co}\right.$, $\mathrm{Fe} \& \mathrm{Ni} \& \mathrm{Co}$ ) with a solid support, HEMA (2-hydroxyethylmethacrylate), and a functional monomer, AdeM (adenine methacrylate), were compared. Some other properties such as size, zeta potential, surface morphology, etc. were also studied.
\end{abstract}

Keywords: Microparticles; magnetic microparticles; polymeric materials.

Submitted: August 16, 2016. Revised: August 25, 2016. Accepted: August 27, 2016.

Cite this: Köse K. Characterization of Magnetic Polymeric Microparticles. JOTCSA. 2016;3(3):185-204.

DOI: $10.18596 /$ jotcsa. 74979.

*Corresponding author. E-mail: kazimkos1903@gmail.com. GSM: +905535478078. 


\section{INTRODUCTION}

There are a variety of applications in the fields such as high-density data storage, ferroliquids, magnetic resonance imaging, wastewater treatment, protein purification, biomedical (1-7), and especially clinical $(8,9)$ areas $(10,11)$. The classical separation and purification techniques have been replaced by magnetic separation methods in terms of the removal of the long steps, including filtration and centrifugation $(12,13)$ or disadvantages like decomposition, inactivation, or deformation of biomolecules (14). The magnetic separation techniques, as expected, requires magnetic particles to satisfy some vital features such as colloidal sustainability, equality in size, low poly dispersity index, the high and equal amount of magnetite content, superparamagnetic behavior, and effective surface functional groups to interact with active biological ligands (15). There is a variety of methods to synthesize magnetic polymeric spheres like emulsion (16) and multistep swelling polymerization (17), solvent evaporation (18), etc. In contrast to these methods, providing very complex or broad polydispersity index, the dispersion polymerization has been suggested as an alternative method to synthesize micron-sized magnetic particles (19). The most crucial advantage of this method is being simple: It is a single-step technique providing mono-size particles under desired conditions (20). The polymeric magnetic particles are quite available candidates in terms of and due to the high mechanical resistance, insolubility and wonderful shelf-life (21), having a variety of surface functional groups, (22-26), good mechanical features, easy preparation, and biocompatibility developed for bio-friendly components (27). Poly(2-hydroxyethyl methacrylate) [Poly(HEMA)] has been considered as a suitable matrix for enzyme immobilization due to being a biocompatible synthetic polymer with a good mechanical strength for several biomedical and biotechnological applications (28). Magnetic separation techniques have a number of applications in biosciences especially in laboratory scale (29). The magnetic separation is very fast and simple with the requirement only a simple apparatus, namely magnetite (30). The magnetic carriers also decrease the cost of operation and supply (31-34). Beside the providing solution for diffusion limitation, nanoparticles providing the increase of the adsorption capacity of the solid support are alternative for the macroporous microparticles $(3,21,35,36)$. High surface area and lack of carrying limitations make the magnetic nanoparticles the desired choice for the purification of biomolecules (37). However, the main problem in the use of nanoparticles is agglomeration. In this aspect, researchers should be very careful while using nanoparticles. 
Spinel ferrite (SF) magnetic materials are an important class of metal oxide composites including iron ions with the structural formula of $\mathrm{M}^{2+} \mathrm{Fe}_{2}{ }^{3+} \mathrm{O}_{4}\left(\mathrm{M}=\mathrm{Mg}^{2+}, \mathrm{CO}^{2+}, \mathrm{Ni}^{2+}, \mathrm{Zn}^{2+}\right.$, $\mathrm{Fe}^{2+}, \mathrm{Mn}^{2+}$, etc.). SFs have unique properties such as perfect magnetic characteristic, high surface area, surface active sites, surface chemical stability, controllable size, and easy functionalization and modification. Because of multi-functionality, being cost effective, and high capacity of magnetic separation, SF adsorbents are the first as a choice for the purification process with the requirement of high adsorption effectivity and fast kinetics (38).

Iron-oxide based materials are at the center for the nanostructured magnetic materials and because of the being naturally abundant, cost-effective and environmentally friendly, they are studied in a large spectrum of research (38).

Iron(III) oxide $\left(\mathrm{Fe}_{2} \mathrm{O}_{3}\right)$ or iron(II-III) oxide $\left(\mathrm{Fe}_{3} \mathrm{O}_{4}\right)(39)$ and also $\mathrm{Fe} \& \mathrm{Ni}(40)$ and $\mathrm{Fe} \& \mathrm{Co}$ $(41,42)$ double salts were used to get magnetic polymeric materials in some studies up to now. There is almost not yet any research with the double salt in the literature. In this study, the salts of $\mathrm{Fe}_{2} \mathrm{O}_{3}$ and $\mathrm{Fe}_{3} \mathrm{O}_{4}, \mathrm{Fe} \& \mathrm{Ni}, \mathrm{Fe} \& \mathrm{Co}, \mathrm{Ni} \& \mathrm{Co}$ and $\mathrm{Fe} \& \mathrm{Ni} \& \mathrm{Cu}$ structures were synthesized and the polymeric particles with these salts were compared in terms of size, magnetism, etc.

\section{MATERIAL AND METHODS}

\section{Material}

The chemicals [cobalt(II) nitrate hexahydrate, iron(II) nitrate nonahydrate, toluene, sodium nitrite and potassium carbonate] needed for the double salt synthesis process were obtained from Sigma-Aldrich (St. Louis, MO, USA). The polymerization of microparticles was run using polyvinyl alcohol (PVA) (cold water soluble, MW 31,000-50,000), ethylene glycol dimethacrylate (EGDMA), 2-hydroxyethyl methacrylate (HEMA), and methacryloyl chloride obtained from Aldrich (Munich, Germany). The initiator [azobis(isobutyronitrile) (AIBN)] used in this experiment obtained from Fluka (St. Gallen, Switzerland). $\mathrm{Fe}_{2} \mathrm{O}_{3}$ and $\mathrm{Fe}_{3} \mathrm{O}_{4} \mathrm{~N}$-methacryloyl adenine (43) and double and triple salts [Fe(II)-Co(II), $\mathrm{Fe}$ (II)-Ni(II), $\mathrm{Ni}(\mathrm{II})-\mathrm{Co}(\mathrm{II}), \mathrm{Fe}$ (II)-Co(II)-Ni(II)] (44) used were synthesized in the laboratory according to the literature (42). Monomers were maintained in a refrigerator at $4{ }^{\circ} \mathrm{C}$ until use. The remaining chemicals not mentioned above are of analytical grade. 


\section{Methods}

First step, synthetic process of poly(HEMA-AdeM) microparticles with magnetic core: The suspension polymerization technique was used to obtain m-poly(HEMA-AdeM) microparticles (45). $50 \mathrm{mg}$ of adenine methacrylate (AdeM) was added to the mixture of 2 $\mathrm{mL}$ of 2-hydroxyethyl methacrylate and $4 \mathrm{~mL}$ of ethylene glycol dimethacrylate. After AdeM was totally dissolved, toluene $(6 \mathrm{~mL})$ was added as a diluent. $200 \mathrm{mg}$ of polyvinyl alcohol and $50 \mathrm{~mL}$ of distilled water were mixed to have dispersion medium. Before treatment with nitrogen gas, the two media were mixed with each other. The polymerization process was started with the addition of $50 \mathrm{mg}$ azobis(isobutyronitrile) and also $1 \mathrm{~g}$ of the magnetic core $\left(\mathrm{Fe}_{2} \mathrm{O}_{3}\right.$ and $\mathrm{Fe}_{3} \mathrm{O}_{4}$ for $\mathrm{mc}^{-} \mathrm{Fe}_{2} \mathrm{O}_{3} \& \mathrm{Fe}_{3} \mathrm{O}_{4}$-poly(HEMA-AdeM), Fe-Ni double salt for mcFe \& Ni-poly(HEMA-AdeM), Fe-Co double salt for mc-Fe \& Co-poly(HEMA-AdeM), Ni-Co double salt for mc-Ni \& Co-poly(HEMA-AdeM) and Fe-Ni-Co triple salt for mc-Fe \& Ni \& Copoly(HEMA-AdeM)). The polymerization process was completed at the end of stirring (the conditions; $500 \mathrm{rpm}, 65^{\circ} \mathrm{C}, 6 \mathrm{~h}$ and $650 \mathrm{rpm}, 85^{\circ} \mathrm{C}, 2 \mathrm{~h}$ ) for 8 hours. All microparticles were washed to get rid of the unreacted chemicals and other contaminants, and they were remained under vacuum at $45-50{ }^{\circ} \mathrm{C}$ for a day.

Second step, characterization process: The magnetic properties owned by the microparticles were determined using vibrating sample magnetometer (VSM) (Quantum Design, Physical Properties Measurement System (PPMS), USA). The hysteresis curves for all particles were obtained under the external magnetic field of 20,000/+20,000 G at room temperature. The surface morphology of microparticles was determined using scanning electron microscopy (SEM; Carl Zeiss AG - EVOR 50 Series, Germany). The microparticles were dried at $50{ }^{\circ} \mathrm{C}$ overnight before the analysis. The Fourier transform infrared spectroscopy (FT-IR, Thermo Scientific Nicolet 6700 FT-IR spectrometer, USA) was used in the wavenumber range of $400-4000 \mathrm{~cm}^{-1}$ to identify the characteristic peaks obtained from structures, especially nitrogen containing AdeM molecules. $98 \mathrm{mg}$ of IR-grade $\mathrm{KBr}$ was mixed with the microparticles of approximately $1 \mathrm{~g}$. The Brunauer-Emmett-Teller (BET), (Quantachrome Autosorb $®$ iQ-Chemi, USA) analysis was performed to investigate the specific surface area of microparticles. Carefully dried microparticles using vacuum oven under the conditions of 20 mbar, $6 \mathrm{~h}$ were run the adsorption of nitrogen gas at $200^{\circ} \mathrm{C}$, but the desorption process at room temperature. 


\section{RESULTS AND DISCUSSION}

\section{Characterization Data}

The structure of microparticles synthesized in this study was assumed as given in Figure 1. As can be understood from the figure, there is a magnetic core in the center and the polymerization of HEMA and the monomer form of adenine were polymerized by surrounding of the magnetic core. As a result of this polymerization, spherical microparticles were obtained.

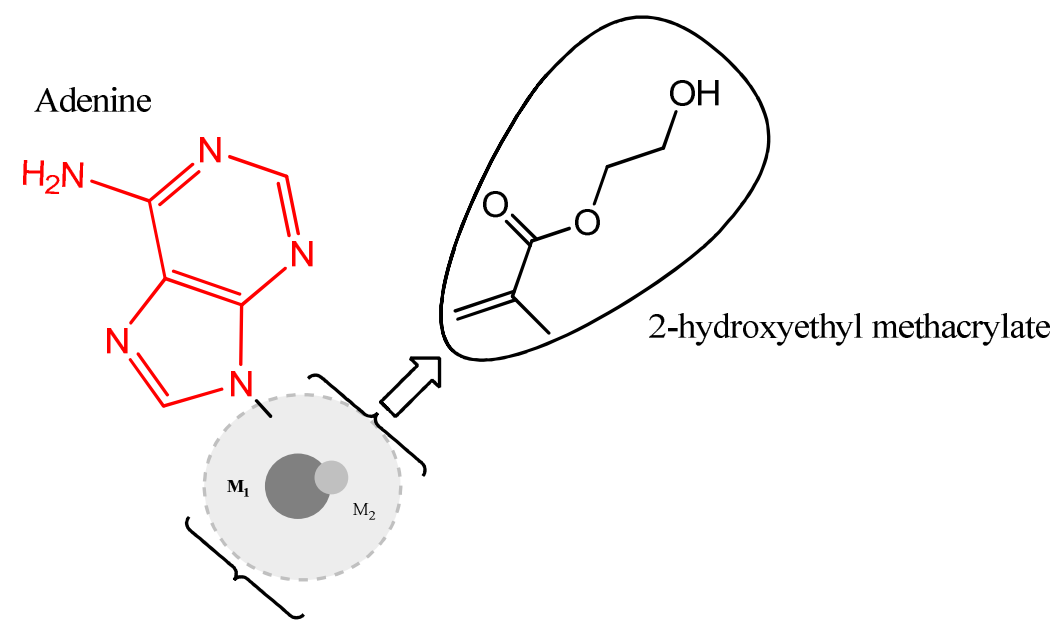

Figure 1. Expected polymeric structure of mc-M1\&M2-poly(HEMA-AdeM) microparticles.

From the FTIR spectral data, the synthesis of m-poly(HEMA-AdeM) microparticles was proved by the bands obtained especially at $1636.03 \mathrm{~cm}^{-1}$ for amide (I and II), at 1558.17 $\mathrm{cm}^{-1}$ and $1456.44 \mathrm{~cm}^{-1}$ for ester, at $1730.94 \mathrm{~cm}^{-1}$ for carbonyl $(\mathrm{C}=0)$ stretching and at $1071.84 \mathrm{~cm}^{-1}$ for $\mathrm{C}-\mathrm{N}=\mathrm{C}$ stretching (Figure 2 ). 


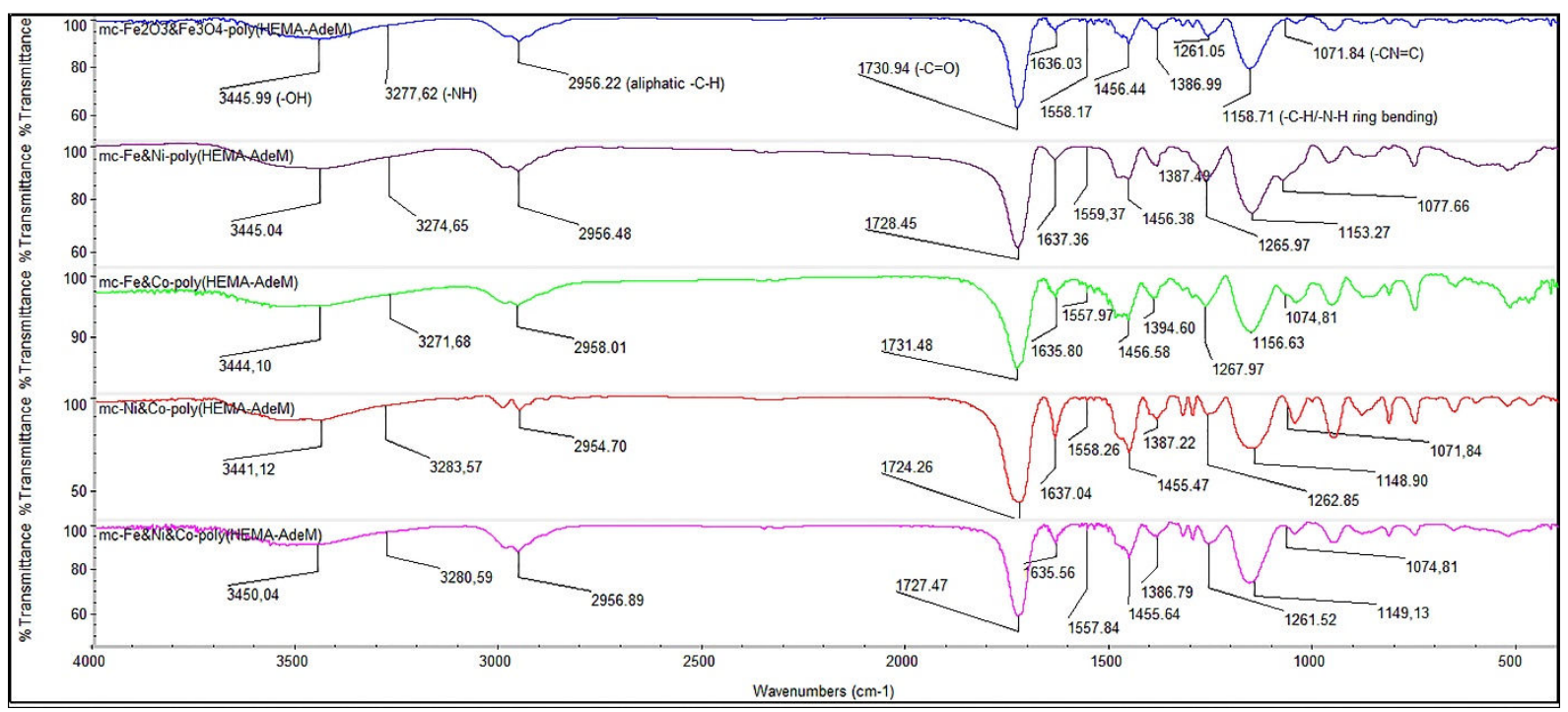

Figure 2. FTIR spectra of microparticles.

The perfect spherical structure and rough surface of microparticles can be seen in the SEM images of the m-poly(HEMA-AdeM) microparticles (Figure 3). The roughness is actually advantageous in terms of the existence of functional groups and the attachment of target molecules. Moreover, some of the microparticles like in Figure 3.b are equidimensional, but some are not. The reason for this may be the slight daily changes in environmental conditions, personal error or the characteristics of the magnetic core. After all, the polydispersity indexes of all microparticles obtained are almost $<0.5$.
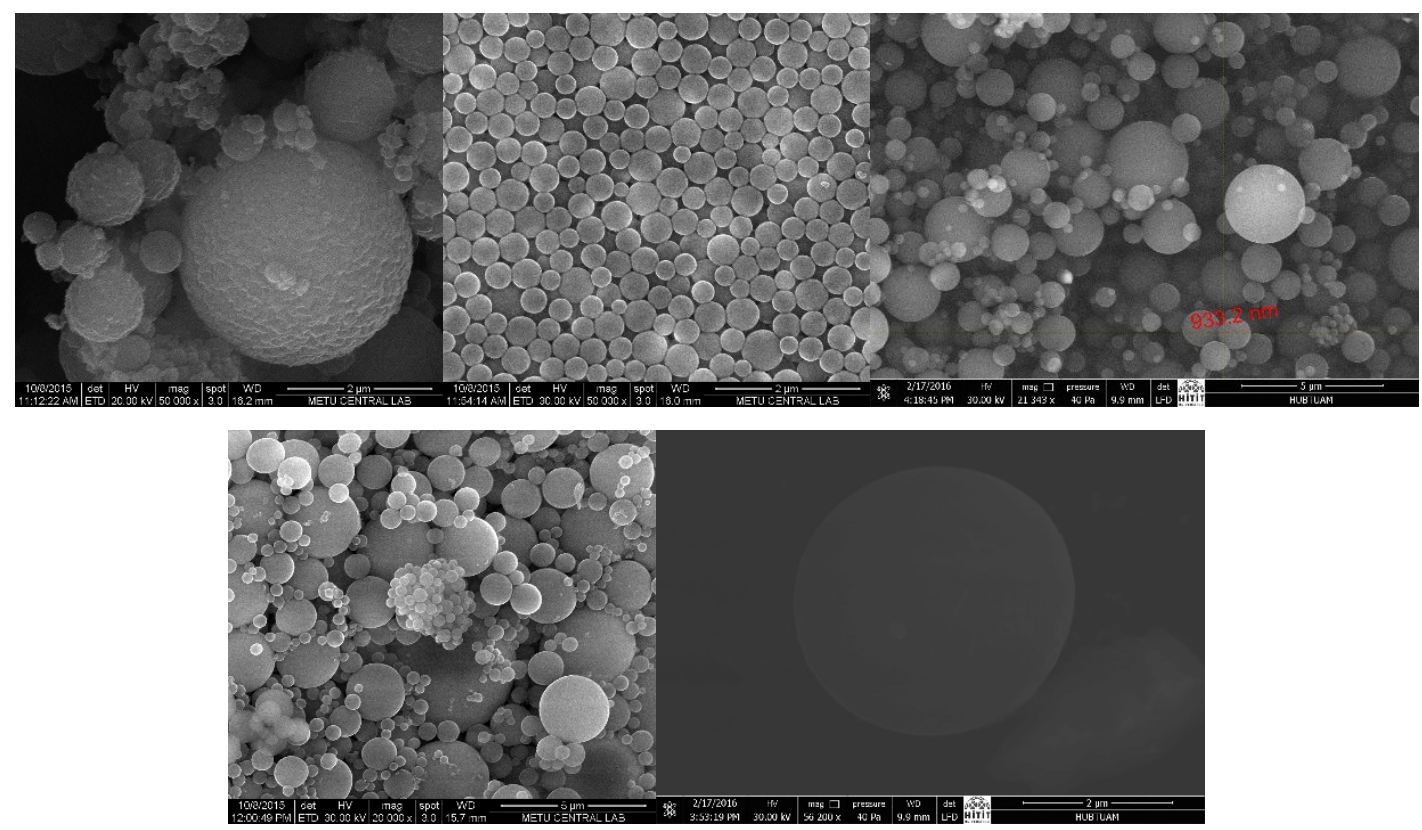

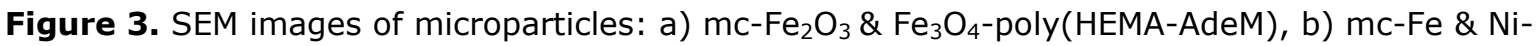
poly(HEMA-AdeM), c) mc-Fe \& Co-poly(HEMA-AdeM), d) mc-Ni \& Co-poly(HEMA-AdeM), e) mc-Fe \& Ni \& Co-poly(HEMA-AdeM). 
The theoretical sizes of the magnetic core were calculated as given in Table 1 . The polymeric microparticles with Fe \& Co magnetic core have the lowest ionic radii, in parallel with this the highest is $\mathrm{Fe} \& \mathrm{Ni} \&$ Co magnetic core as expected due to the number of the metallic cores which is one more than the former. However, in the light of BrunauerEmmett-Teller (BET) analyses (the specific surface areas given in Table 2), it is obvious that the molecular size and also the double salt character affect the size construction of microparticles and thus specific surface area. From the data, the lowest particle size and thus the highest surface area are owned by the mc-Fe \& Ni-poly(HEMA-AdeM) microparticles. The reason for this contradiction may be attributed to the interaction between the metals and the polymeric structure, i.e. the interaction between $\mathrm{Fe} \& \mathrm{Ni}$ is somewhat higher than that of Fe \& Co or the polymerization process around the metallic core. Moreover, the microparticles with the large surface area will have a high amount of adsorption capacity. This is also proof of a thin polymer layer surrounded over magnetic core.

Another useful data given in Table 2 is the zeta potential, providing the degree of intermolecular interaction. As can be seen from the table, all microparticles have good zeta potential values indicating the existence of almost no intermolecular interaction microparticles have.

Table 1. The theoretical size of magnetic cores formed by double and triple salts.

\begin{tabular}{lcccc}
\hline & $\mathrm{Fe}$ & $\mathrm{Ni}$ & $\mathrm{Co}$ & Total \\
\hline Ionic radius & & & & \\
\hline Fe-Ni & 0.55 & 0.69 & & 1.24 \\
Fe-Co & 0.55 & & 0.65 & 1.20 \\
Ni-Co & & 0.69 & 0.65 & 1.34 \\
Fe-Ni-Co & 0.55 & 0.69 & 0.65 & 1.89 \\
\hline
\end{tabular}


Table 2. Some specific properties of microparticles.

\begin{tabular}{|c|c|c|c|c|c|c|c|}
\hline Microparticles & $\begin{array}{l}\text { Size } \\
(\mu)\end{array}$ & $\begin{array}{l}\text { S. Area } \\
\left(\mathrm{m}^{2} / \mathrm{g}\right)\end{array}$ & $\begin{array}{l}\text { BJH S. Area } \\
\left(\mathrm{m}^{2} / \mathrm{g}\right)\end{array}$ & $\begin{array}{l}\text { Pore Volume } \\
(\mathrm{cc} / \mathrm{g})\end{array}$ & $\begin{array}{l}\text { Pore Radius Dv } \\
(\mathbf{r})(\AA)\end{array}$ & $\begin{array}{l}\text { Zeta Pot. } \\
(\mathrm{mV})\end{array}$ & $\begin{array}{l}\text { Ligand Incorp. } \\
(\mathrm{N} \%)\end{array}$ \\
\hline $\begin{array}{l}\text { 1) mc-Fe2O3 \& Fe3O4-poly(HEMA- } \\
\text { AdeM) }\end{array}$ & 2.745 & 39.178 & 35.647 & 0.155 & 17.078 & -24.9 & 1.08 \\
\hline 2) mc-Fe \& Ni-poly(HEMA-AdeM) & 1.534 & 113.478 & 91.376 & 0.380 & 21.566 & 8.06 & 1.08 \\
\hline 3) mc-Fe\&Co-poly(HEMA-AdeM) & 2.545 & 51.216 & 36.687 & 0.084 & 17.063 & -24.1 & 0.79 \\
\hline 4) mc-Ni\&Co-poly(HEMA-AdeM) & 3.452 & 6.884 & 5.367 & 0.040 & 15.280 & -23.8 & 0.82 \\
\hline 5) mc-Fe \& Ni\&Co-poly(HEMA-AdeM) & 4.446 & 4.103 & 3.248 & 0.026 & 17.082 & -22.9 & 0.53 \\
\hline
\end{tabular}


The hysteresis curves of m-poly(HEMA-AdeM) microparticles are given in Figure 4. According to these curves, it is obvious that all microparticles have significant paramagnetic character. There was a loss observed in the magnetic behavior, which may be because of the oxidation during the process causing the iron oxide, nickel oxide, and cobalt oxide molecules, actually nonmagnetic, in the chain of polymeric materials. The main reason for this phenomenon is the oxidizing initiator fragment. In the light of the Mrs/Ms values of microparticles (0.1-0.3), it can be concluded that the microparticles synthesized in the scope of this study all have almost natural magnetism due to the pseudo-single-domain grains (46). These particles are irregularly-shaped and thus they have domain imbalance resulting in stability to thermal demagnetization and alternating field. Consequently, as can be seen from the figure, the mc-Fe \& Ni-poly(HEMA-AdeM) microparticles have the highest and regular magnetism. However, the magnetism of Fe \& Co double salt incorporated polymeric material should be higher than that of $\mathrm{Fe} \& \mathrm{Ni}$ because of smaller size and higher electron delocalization resulting higher magnetic field, but it is not. The explanation may be the negative effect of $\mathrm{Co}(\mathrm{II})$, $d^{7}$ metal with 3 paramagnetic $d$ orbitals but $\mathrm{Ni}(\mathrm{II})$, a $\mathrm{d}^{8}$ metal, has two paramagnetic orbitals diminishing the magnetic power of iron, on the $d$ orbitals of the Fe which is the source of Fe magnetism, and thus the magnetic power of iron may be diminished but less for the nickel case. As a conclusion, the magnetism of Fe \& Ni is a little bit higher than that of Fe \& Co double salt incorporated polymeric material.

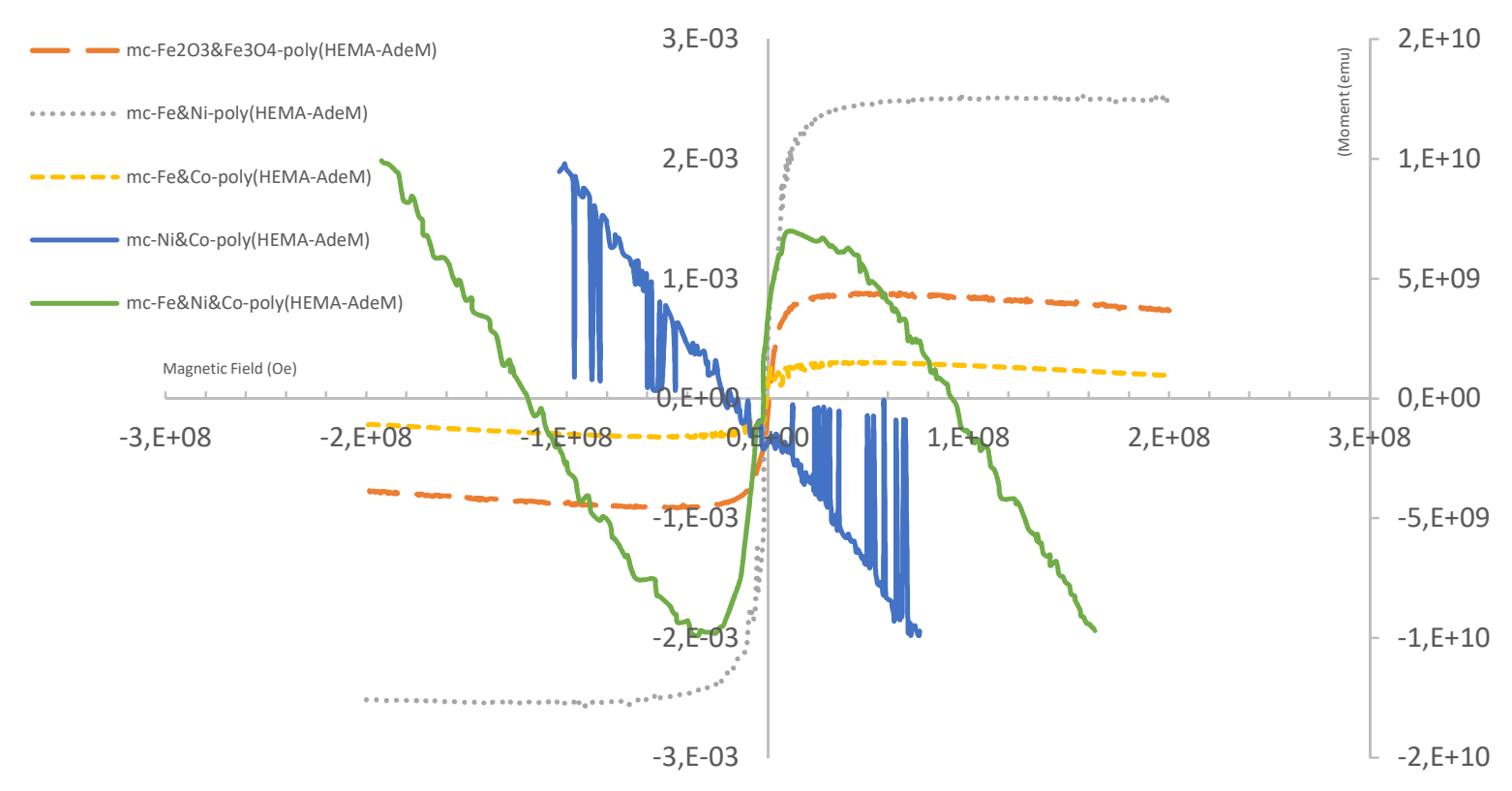

Figure 4. The magnetic hysteresis curves for microparticles. 
The application of an external field to the sample may create an internal field which may be added to or subtracted from external field. To produce local magnetic effective field

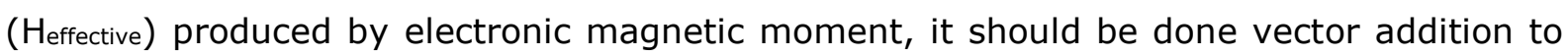
the external magnetic field (Hexternal).

$$
H_{\text {effective }}=H_{\text {external }}+H_{\text {local }}
$$

The molecules with an unpaired electron can be analyzed using an electron spin resonance device (ESR, Bruker ELEXSYS E580, Germany), indicating whether these molecules have a magnetic feature or not. This method also proves the incorporation of magnetic double salts into the polymeric structure.

An external magnetic field applied to a material with an unpaired electron pair produces energy levels with the energy difference known as $\Delta \mathrm{E}$ depending on magnetic moments. The difference between these energy levels is equal to $\Delta E=g . \beta . H$. The magnetic field at the time of equivalence of the energy difference to the microwave energy is defined as the resonance field $\left(\mathrm{H}_{\mathrm{r}}\right)$. The resonance field is the value of magnetic field at the point that the signal intensity in the ESR spectrum is zero, i.e., the maximum microwave energy was absorbed. The $\mathrm{g}$ factor indicates the characteristic amount of molecules on which the unpaired electron pairs are located. For example, the $g$ values for iron, nickel, and cobalt are $2.09,2.21$, and 2.18 (47). For the identification of an unknown signal, it is better to determine the $\mathrm{g}$ factor. The $\mathrm{g}$ factors for the mc-Fe \& Ni-poly(HEMA-AdeM) and mc- $\mathrm{Fe}_{2} \mathrm{O}_{3}$ $\& \mathrm{Fe}_{3} \mathrm{O}_{4}$-poly(HEMA-AdeM) microparticles were calculated as 2.3 and 2.68, respectively, according to the formula given. Moreover, the magnetic field value, $\mathrm{H}_{r}$, obtained from the graph was 3023 and 2582 gauss for the mc-Fe \& Ni-poly(HEMA-AdeM) and mc- $\mathrm{Fe}_{2} \mathrm{O}_{3}$ \& $\mathrm{Fe}_{3} \mathrm{O}_{4}$-poly(HEMA-AdeM) microparticles, respectively, which are the sufficient values for the stimulation of all dipole moments in the mc-Fe \& Ni-poly(HEMA-AdeM) and mc- $\mathrm{Fe}_{2} \mathrm{O}_{3}$ \& $\mathrm{Fe}_{3} \mathrm{O}_{4}$-poly(HEMA-AdeM) microparticle samples of $1 \mathrm{~g}$ each (Figure 5).

$$
g=\frac{h \cdot \vartheta}{\beta \cdot H_{r}}
$$

Wherein $\mathrm{h}$ is the Planck's constant $\left(6.626 \times 10^{-27} \mathrm{erg} \times \mathrm{s} \mathrm{s}^{-1}\right), \vartheta$ is the frequency $(9.707 \mathrm{x}$ $\left.10^{9} \mathrm{~Hz}\right), \beta$ is the universal constant $\left(9.274 \times 10^{-21} \mathrm{erg} \times \mathrm{G}^{-1}\right)$ and the $\mathrm{Hr}$ is the magnetic field resonance $(G)$. 


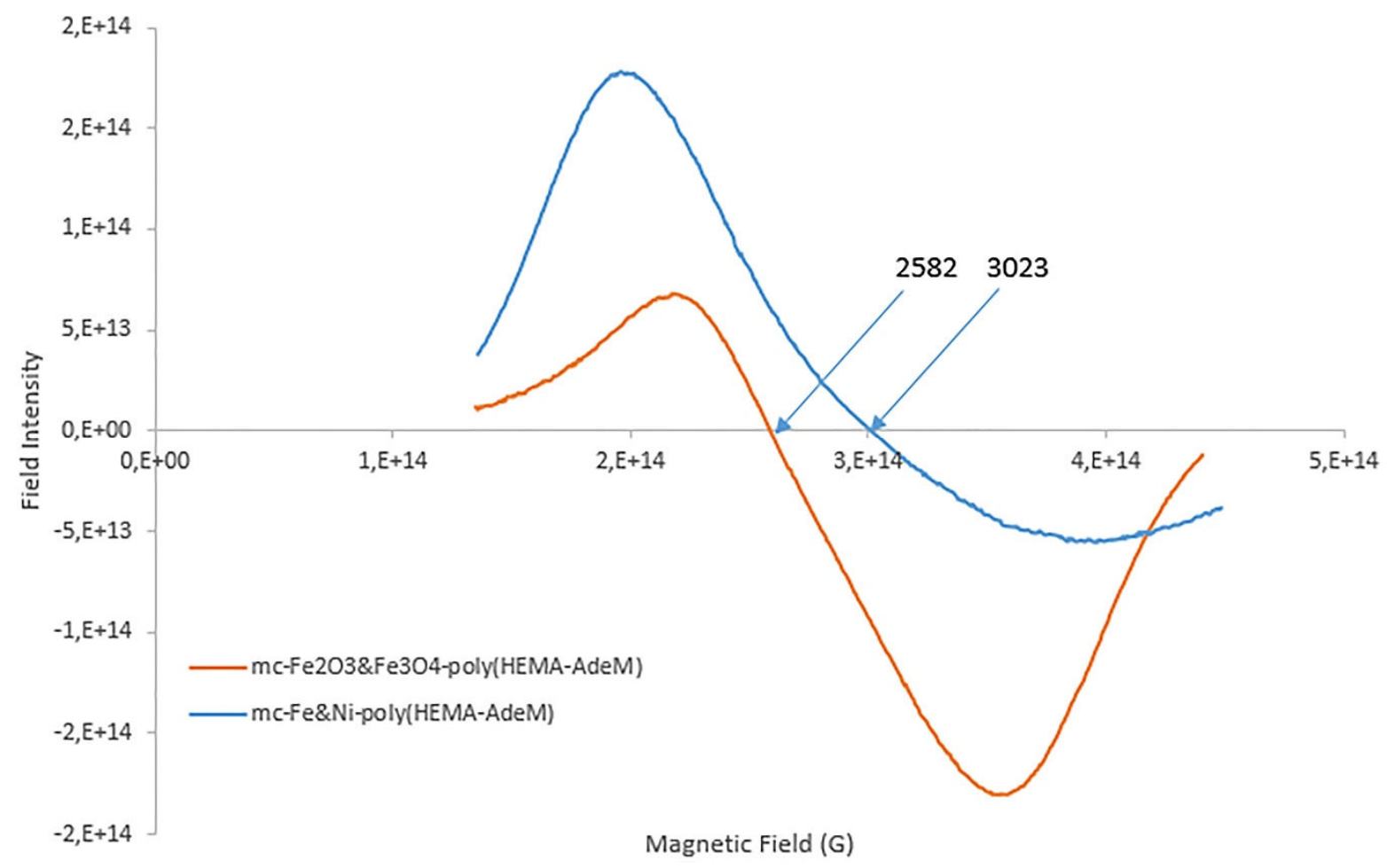

Figure 5. The ESR spectra of mc-Fe \& Ni-poly(HEMA-AdeM) and mc- $\mathrm{Fe}_{2} \mathrm{O}_{3} \& \mathrm{Fe}_{3} \mathrm{O}_{4}$-poly(HEMAAdeM) microparticles.

On the contrary to mc-Fe \& Ni-poly(HEMA-AdeM) and mc- $\mathrm{Fe}_{2} \mathrm{O}_{3} \& \mathrm{Fe}_{3} \mathrm{O}_{4}$-poly(HEMA-AdeM) microparticles, there were no $\mathrm{Hr}_{r}$ points observed for other microparticles synthesized in this study. The reason for this result may be the same with the cause given above about the $d$ orbitals and overlapping of energies. This result does not mean that other microparticles have no magnetic behavior but very minor as compared to the both of mc$\mathrm{Fe} \& \mathrm{Ni}$-poly(HEMA-AdeM) and mc- $\mathrm{Fe}_{2} \mathrm{O}_{3} \& \mathrm{Fe}_{3} \mathrm{O}_{4}$-poly(HEMA-AdeM) microparticles.

The microparticles synthesized in this study have also significant water swelling ability. The porous structure of microparticles is very convenient to uptake water. In the adsorption process, the water swelling ratio is very important; because of that, the more water diffuses to the pores, the more interaction between ligand and target molecules occurs. According to Figure 6 , the water uptake ability of mc-Fe \& Ni-poly(HEMA-AdeM) microparticles is almost the same with that of the mc-Fe \& Ni-Co-poly(HEMA-AdeM) microparticles, which is the highest in the group. If these data are compared with those in Table 2, it can be inferred that the mc-Fe \& Ni-poly(HEMA-AdeM) microparticles are also highly adequate for water swelling. 


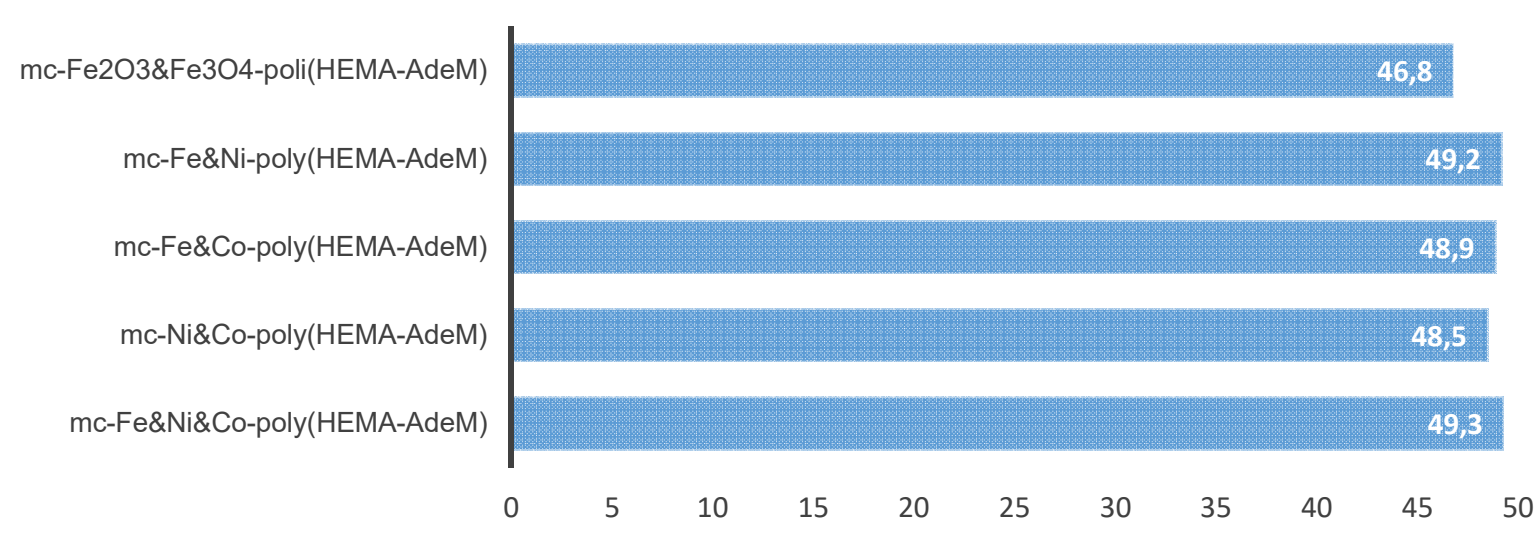

Figure 6. The water swelling ability of microparticles.

It can be concluded as a summary of all characterization steps that the mc-Fe \& Nipoly(HEMA-AdeM) microparticles are almost equidimensional with the lowest size (which is important for the surface area and effectivity) and thus the highest surface area (important for the interaction number and thus the amount to be adsorbed) as compared to other microparticles according to the SEM images. According to the theoretical size of double salts, the lowest theoretical size belongs to the Fe-Co magnetic core, but this does not mean the polymeric material in which the Fe-Co magnetic core was incorporated will have the lowest particles size; actually the size of polymeric microparticles is directly related with the polymerization conditions which are all the same for all polymeric microparticles and also the interaction of the magnetic core with the monomers and other chemicals needed in polymerization step. This interaction, according to the results, was happened as highly effective for Fe-Ni magnetic core and thus mc-Fe \& Ni-poly(HEMAAdeM) microparticles. Moreover, the pore volume and also the water swelling ability obtained as a result of polymerization step is the highest for mc-Fe \& Ni-poly(HEMA-AdeM) microparticles meaning that the diffusion of the matrix into the pores of mc-Fe \& Nipoly(HEMA-AdeM) microparticles will be the highest and thus interaction and adsorption. In this point, the water swelling of mc-Fe \& Ni \& Co-poly(HEMA-AdeM) microparticles is a tiny little bigger than the mc-Fe \& Ni-poly(HEMA-AdeM) microparticles, but it does not make sense because of other characterization results. With respect to the results, all polymeric microparticles have ideal zeta potentials, meaning the lowest inter- and intramolecular interactions with each other are present. In the light of the characterization of magnetism, the mc-Fe \& Ni-poly(HEMA-AdeM) microparticles have the highest magnetic moments as compared to even mc- $\mathrm{Fe}_{2} \mathrm{O}_{3} \& \mathrm{Fe}_{3} \mathrm{O}_{4}$-poly(HEMA-AdeM) microparticles which is the only structure having the $\mathrm{H}_{r}$ value other that mc-Fe \& Ni-poly(HEMA-AdeM) microparticles. Therefore, one should compare these to structure in terms of magnetism and also applicability. As seen, the magnetic hysteresis curve of $\mathrm{mc}^{-} \mathrm{Fe}_{2} \mathrm{O}_{3} \& \mathrm{Fe}_{3} \mathrm{O}_{4}-$ 
poly(HEMA-AdeM) microparticles is very low as compared to mc-Fe \& Ni-poly(HEMA-AdeM) meaning the magnetic moment of former is very low as compared to latter, i.e., magnetism. As given above, The ESR spectrum was obtained only for both $\mathrm{mc}-\mathrm{Fe}_{2} \mathrm{O}_{3} \&$ $\mathrm{Fe}_{3} \mathrm{O}_{4}$-poly(HEMA-AdeM) and mc-Fe \& Ni-poly(HEMA-AdeM) microparticles and thus $\mathrm{Hr}_{\mathrm{r}}$ value needed for the stimulation of dipole moments in the molecule which is bigger for mcFe \& Ni-poly(HEMA-AdeM) microparticles (better if it is low). Overall, a researcher may choose the $\mathrm{Fe}-\mathrm{Ni}$ magnetic core for the synthesis of magnetic polymeric micro- or nanoparticles for a separation process due to the promising features of this double salt core.

\section{CONCLUSION}

The polymeric microparticles are very good materials used in a wide variety of fields from the cleaning of wastewater to isolation of DNA as indicated above. Therefore, in this respect, the efficiency of microparticles is very important. Up to date, there are so many studies about the improvements of the functionality of microparticles and also there have been lots of ligands developed to interact with these microparticles. Especially, magnetic microparticles are very good at the magnetic separation of biomolecules in almost single or double steps. The double salts or microparticles containing double salts are very new in the literature and also very effective. The magnetism of these double salts or other features affects the microparticle formation, composition, and also the structure. Which double salt or which magnetic core is promising for the isolation, removal or purification of biomolecules is very vital in terms of time, efficiency, labor or purity of biomolecules obtained. In this study, some double salts and iron oxide structure were used to synthesize microparticles for the investigation of the effect of double salt on the functionality or performance of microparticles obtained. As noted in the text, mc-Fe \& Ni-poly(HEMA-AdeM) microparticles passed all steps in success. The reason for this may be attributed to the $\mathrm{Fe}$ $\& \mathrm{Ni}$ ionic radius, Fe $\& \mathrm{Ni}$ magnetism, and the efficient interaction with polymeric structure because of their useful orbitals pulling negatively charged structures of polymeric material around them. The researchers studying polymeric materials for the removal, isolation, or purification of biomolecules may consult these data prior to their studies. 


\section{ACKNOWLEDGMENTS}

The author thanks Assoc. Prof. Dr. D. Ali Köse from Hitit University (Çorum, Turkey) for his very kind help and permission to use the available devices.

\section{REFERENCES}

1. Josephson L, Tung C-H, Moore A, Weissleder R. High-efficiency intracellular magnetic labeling with novel superparamagnetic-Tat peptide conjugates. Bioconjugate chemistry. 1999;10(2):186-91.

2. Partington KM, Jenkinson EJ, Anderson G. A novel method of cell separation based on dual parameter immunomagnetic cell selection. Journal of immunological methods. 1999;223(2):195-205.

3. Türkmen $D$, Yavuz $H$, Denizli A. Synthesis of tentacle type magnetic beads as immobilized metal chelate affinity support for cytochrome $\mathrm{c}$ adsorption. International journal of biological macromolecules. 2006;38(2):126-33.

4. Park J-H, Im K-H, Lee S-H, Kim D-H, Lee D-Y, Lee Y-K, et al. Preparation and characterization of magnetic chitosan particles for hyperthermia application. Journal of Magnetism and Magnetic Materials. 2005;293(1):328-33.

5. Lübbe AS, Alexiou C, Bergemann C. Clinical applications of magnetic drug targeting. Journal of Surgical Research. 2001;95(2):200-6.

6. Hinds KA, Hill JM, Shapiro EM, Laukkanen MO, Silva AC, Combs CA, et al. Highly efficient endosomal labeling of progenitor and stem cells with large magnetic particles allows magnetic resonance imaging of single cells. Blood. 2003;102(3):867-72.

7. Mornet S, Vasseur S, Grasset F, Duguet E. Magnetic nanoparticle design for medical diagnosis and therapy. Journal of Materials Chemistry. 2004;14(14):2161-75.

8. Serda RE, Adolphi NL, Bisoffi M, Sillerud LO. Targeting and cellular trafficking of magnetic nanoparticles for prostate cancer imaging. Molecular imaging. 2007;6(4):277.

9. Ranzoni A, Sabatte G, van IJzendoorn LJ, Prins MW. One-step homogeneous magnetic nanoparticle immunoassay for biomarker detection directly in blood plasma. Acs Nano. 2012;6(4):3134-41.

10. Fee CJ. Stability of the liquid-fluidized magnetically stabilized fluidized bed. AIChE journal. 1996;42(5):1213-9. 
11. Graves D. Bioseparations in the Magnetically Stabilized Fluidized Bed, Chapter 9, 187207 Barker and Ganetsos, Eds., Preparative and Production Scale Chromatography. Marcel Dekker, Inc., NY; 1993.

12. Sawakami-Kobayashi K, Segawa O, Obata K, Hornes E, Yohda M, Tajima H, et al. Multipurpose robot for automated cycle sequencing. Biotechniques. 2003;34(3):634-7.

13. Tanaka T, Matsunaga T. Fully automated chemiluminescence immunoassay of insulin using antibody-protein A-bacterial magnetic particle complexes. Analytical chemistry. $2000 ; 72(15): 3518-22$.

14. Idil N, Perçin I, Karakoç V, Yavuz H, Aksöz N, Denizli A. Concanavalin A immobilized magnetic poly (glycidyl methacrylate) beads for prostate specific antigen binding. Colloids and Surfaces B: Biointerfaces. 2015;134:461-8.

15. Zheng W, Gao F, Gu H. Carboxylated magnetic polymer nanolatexes: preparation, characterization and biomedical applications. Journal of magnetism and magnetic materials. 2005;293(1):199-205.

16. Pollert E, Knížek K, Maryško M, Závěta K, Lančok A, Boháček J, et al. Magnetic poly (glycidyl methacrylate) microspheres containing maghemite prepared by emulsion polymerization. Journal of magnetism and magnetic materials. 2006;306(2):241-7.

17. Lea T, Vartdal F, Davies C, Ugelstad J. Magnetic monosized polymer particles for fast and specific fractionation of human mononuclear cells. Scandinavian journal of immunology. 1985;22(2):207-16.

18. Ramanujan R, Chong W. The synthesis and characterization of polymer coated iron oxide microspheres. Journal of Materials Science: Materials in Medicine. 2004;15(8):901-8.

19. Jayachandran KNN, Chatterji PR. Preparation of linear and crosslinked polymer microspheres by dispersion polymerization. Journal of Macromolecular Science, Part C: Polymer Reviews. 2001;41(1-2):79-94.

20. Horak D, Lednický F, Petrovský E, Kapička A. Magnetic characteristics of ferrimagnetic microspheres prepared by dispersion polymerization. Macromolecular Materials and Engineering. 2004;289(4):341-8.

21. Uygun DA, Karagözler AA, Akgöl S, Denizli A. Magnetic hydrophobic affinity nanobeads for lysozyme separation. Materials Science and Engineering: C. 2009;29(7):2165-73.

22. Safarik I, Safarikova M. Magnetic techniques for the isolation and purification of proteins and peptides. BioMagnetic Research and Technology. 2004;2(1):1. 
23. Özkara S, Akgöl S, Çanak Y, Denizli A. A Novel Magnetic Adsorbent for Immunoglobulin-G Purification in a Magnetically Stabilized Fluidized Bed. Biotechnology progress. $2004 ; 20(4): 1169-75$.

24. Takahashi K, Hiwada K, Kokubu T. Occurrence of anti-gizzard P34K antibody cross-reactive components in bovine smooth muscles and non-smooth muscle tissues. Life sciences. 1987;41(3):291-6.

25. Hu T-T, Wu J-Y. Study on the characteristics of a biological fluidized bed in a magnetic field. Chemical engineering research \& design. 1987;65(3):238-42.

26. Burns MA, Graves DJ. Continuous affinity chromatography using a magnetically stabilized fluidized bed. Biotechnology progress. 1985;1(2):95-103.

27. Rebroš M, Rosenberg M, Mlichova Z, Krištofíková L'. Hydrolysis of sucrose by invertase entrapped in polyvinyl alcohol hydrogel capsules. Food Chemistry.

2007;102(3): 784-7.

28. Denizli A, Özkan G, Arica MY. Preparation and characterization of magnetic polymethylmethacrylate microbeads carrying ethylene diamine for removal of $\mathrm{Cu}$ (II), Cd (II), Pb (II), and $\mathrm{Hg}$ (II) from aqueous solutions. Journal of applied polymer science. $2000 ; 78(1): 81-9$.

29. Xue B, Sun Y. Protein adsorption equilibria and kinetics to a poly (vinyl alcohol)based magnetic affinity support. Journal of Chromatography A. 2001;921(2):109-19.

30. Tüzmen N, Kalburcu T, Denizli A. a-Amylase immobilization onto dye attached magnetic beads: Optimization and characterization. Journal of Molecular Catalysis B: Enzymatic. 2012;78:16-23.

31. Martin C, Cuellar J. Synthesis of a novel magnetic resin and the study of equilibrium in cation exchange with amino acids. Industrial \& engineering chemistry research. 2004;43(2):475-85.

32. Akgöl S, Türkmen D, Denizli A. Cu (II)-incorporated, histidine-containing, magnetic-metal-complexing beads as specific sorbents for the metal chelate affinity of albumin. Journal of applied polymer science. 2004;93(6):2669-77.

33. Altıntaş EB, Uzun L, Denizli A. Synthesis and characterization of monosize magnetic poly (glycidyl methacrylate) beads. China Part. 2007;5(1):174-9.

34. Tong XD, Sun Y. Application of magnetic agarose support in liquid magnetically stabilized fluidized bed for protein adsorption. Biotechnology progress. 2003;19(6):17217. 
35. Çorman ME, Öztürk N, Tüzmen N, Akgöl S, Denizli A. Magnetic polymeric nanospheres as an immobilized metal affinity chromatography (IMAC) support for catalase. Biochemical Engineering Journal. 2010;49(2):159-64.

36. Shan Z, Wu Q, Wang X, Zhou Z, Oakes KD, Zhang X, et al. Bacteria capture, lysate clearance, and plasmid DNA extraction using $\mathrm{pH}$-sensitive multifunctional magnetic nanoparticles. Analytical biochemistry. 2010;398(1):120-2.

37. Nie L, Gao L, Yan X, Wang T. Functionalized tetrapod-like ZnO nanostructures for plasmid DNA purification, polymerase chain reaction and delivery. Nanotechnology. 2006;18(1):015101.

38. Reddy DHK, Yun Y-S. Spinel ferrite magnetic adsorbents: Alternative future materials for water purification? Coordination Chemistry Reviews. 2016;315:90-111.

39. Kose K, Denizli A. Poly(hydroxyethyl methacrylate) based magnetic nanoparticles for lysozyme purification from chicken egg white. Artif Cell Nanomed B. 2013;41(1):1320.

40. Köse K. Nucleotide incorporated magnetic microparticles for isolation of DNA. Process Biochemistry.

41. Köse K, Erol K, Emniyet AA, Köse DA, Avcı GA, Uzun L. Fe(II)-Co(II) Double Salt Incorporated Magnetic Hydrophobic Microparticles for Invertase Adsorption. Applied Biochemistry and Biotechnology. 2015;177(5):1025-39.

42. Erol K, Kose K, Kose DA, Sizir U, Satir IT, Uzun L. Adsorption of Victoria Blue R (VBR) dye on magnetic microparticles containing Fe(II)-Co(II) double salt. Desalination and Water Treatment. 2016;57(20):9307-17.

43. Hur D, Ekti SF, Say R. N-Acylbenzotriazole mediated synthesis of some methacrylamido amino acids. Letters in Organic Chemistry. 2007;4(8):585-7.

44. Erol K, Köse K, Köse DA, Sızır Ü, Tosun Satır İ, Uzun L. Adsorption of Victoria Blue $\mathrm{R}$ (VBR) dye on magnetic microparticles containing Fe (II)-Co (II) double salt. Desalination and Water Treatment. 2016;57(20):9307-17.

45. Kara A, Osman B, Yavuz H, Beşirli N, Denizli A. Immobilization of a-amylase on Cu $2+$ chelated poly (ethylene glycol dimethacrylate-n-vinyl imidazole) matrix via adsorption. Reactive and Functional Polymers. 2005;62(1):61-8.

46. Fabian K, Hubert A. Shape-induced pseudo-single-domain remanence. Geophysical Journal International. 1999;138(3):717-26. 
47. Baberschke K. Anisotropy in Magnetism. In: Baberschke K, Nolting W, Donath M, Band-Ferromagnetism: Ground-State and Finite-Temperature Phenomena. Berlin, Heidelberg: Springer Berlin Heidelberg; 2001. p. 27-45. 


\section{Türkçe Öz ve Anahtar Kelimeler}

\section{Characterization of Magnetic Polymeric Microparticles}

\section{Kazım Köse}

Öz: Ayırma işlemi, özellikle biyokimya ve biyoteknolojide olmak üzere, bir çok bilim dalında çok önemli bir işlemdir. Bir yöntemin ayırma performansı ayırma zamanı ve hedef molekül için seçilen ligandla doğrudan ilişkili olan, ayrılacak molekülün saflığı ile belirlenebilir. Ayırma zamanı,özellikle tıbbi uygulamalarda olmak üzere zamana bağlı analizlerin ve maliyetin çok önemli bir bileşeni olmaktadır. Manyetik ayırma çok avantajı bir tekniktir, çünkü zaman alan örnek hazırlama ve santrifüjleme adımlarını ortadan kaldırır. Ancak, adsorbanın manyetik performansı, dışarıdan uygulanan manyetik kuvvete cevap verecek kadar kuvvetli olmayabilir. Bu sebepten ötürü, nanoparçacık çalışmalarında nanoparçacıkların manyetik performansı son derece önemlidir. Bu çalışmada, farklı manyetik çekirdeklerin (Fe2O3 \& Fe3O4, Fe \& Ni, Ni\&Co, Fe \& Ni\&Co) HEMA (2-hidroksil etilmetakrilat) ve fonksiyonel bir monomer olan AdeM (adenin metakrilat) kullanılarak sentezlenen polimerik mikroparçacıkların manyetik performansı karşılaştırılmıştır. Boyut, zeta potansiyeli, yüzey morfolojisi gibi diğer bazı özellikler de çalışılmıştır.

Anahtar kelimeler: Mikroparçacıklar, manyetik mikroparçacıklar, polimer malzemeler.

Gönderme: 16 Ağustos 2016. Düzeltme: 25 Ağustos 2016. Kabul: 27 Ağustos 2016. 
